\title{
PENANGANAN NON-PERFORMING FINANCE DALAM AKAD MUSYARAKAH DI BANK KALSEL SYARIAH
}

\author{
Muhammad Rifqi Hidayat \\ Dosen Fakultas Ekonomi dan Bisnis Islam Universitas Islam Negeri Antasari \\ Parman Komarudin
}

Dosen Prodi Hukum Ekonomi Syariah Universitas Islam Kalimantan Muhammad Arsyad al-Banjari

\begin{abstract}
DSN has not specifically regulated the guidelines on handling non-performing financing on musyarakah contracts, while every financing has risks faced by banks and customers, including on musyarakah contracts. Therefore, we conducted a research about how the practice undertaken by Bank Kalsel Syariah in case of problematic financing in musyarakah contract. This research is a qualitative field type with primary data collected through triangulation methods of documents and interviews. The results of the study show that the Sharia Central Bank has four phases in completing nonperforming financing, those phases are cash payments, contract restructuring, collateral settlement, and litigation settlement.
\end{abstract}

Abstrak: DSN belum mengatur secara spesifik mengenai pedoman penanganan pembiayaan bermasalah pada akad musyarakah, sedangkan setiap pembiayaan memiliki risiko yang dihadapi oleh bank maupun nasabah, termasuk pada akad musyarakah. Maka dalam riset ini penulis melakukan penelitian untuk menjawab pertanyaan mengenai bagaimana praktek yang dilakukan oleh Bank Kalsel Syariah apabila terjadi pembiayaan bermasalah pada akad musyarakah. Penelitian ini berjenis kualitatif lapangan dengan data primer yang dikumpulkan melalui metode triangulasi dokumen dan wawancara. Hasil penelitian menunjukkan bahwa Bank Kalsel Syariah memiliki empat tahapan dalam menyelesaikan pembiayaan bermasalah, yaitu pembayaran secara tunai, restrukturisasi akad, penyelesaian melalui jaminan, dan penyelesaian melalui jalur litigasi.

Kata Kunci: Non Performing Finance, Musyarakah

\section{Pendahaluan}

Musyarakah merupakan praktek muamalah yang diperbolehkan oleh agama Islam, hal ini didasarkan pada al-Qur'an seperti yang terdapat pada QS An-Nisa' ayat 12, serta berdasarkan hadits riwayat Abu Hurairah yang berbunyi:

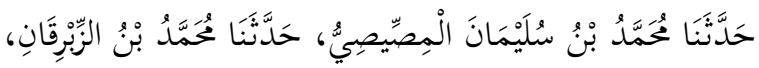

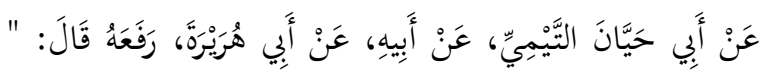

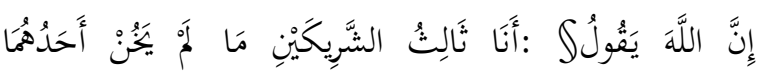

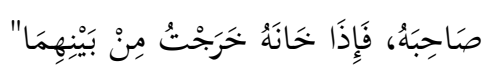

Artinya: "Aku (Allah) merupakan orang ketiga dalam dua orang yang berserikat, selama salah satu dari mereka tidak ada yang berkhianat kepada yang lain. Jika ada yang berkbianat kepada pihak yang lain, maka Aku keluar dari perserikatan di antara mereka"

Musyarakah merupakan perjanjian bagi hasil antara dua belah pihak atau lebih, dimana setiap pihak memberikan dana untuk dicampur kemudian dibuat suatu usaha. Pemilik modal tidak harus ikut serta dalam manajemen perusahaan. Para pihak dapat membagi pekerjaan mengelola usaha sesuai kesepakatan dan mereka juga dapat meminta gaji/upah untuk tenaga dan keahlian yang mereka curahkan untuk usaha tersebut. ${ }^{1}$

Secara praktek, di perbankan syariah musyarakah diperuntukkan kepada pengusaha yang telah memiliki modal sendiri serta usaha yang telah berjalan namun masih ingin mengembangkan usahanya. Dalam hal ini bank menggunakan skema musyarakah dimana masing-masing pihak melakukan kerjasama penyertaan modal. Nasabah kemudian membayar porsi bagi hasil secara rutin sesuai perjanjian kepada bank dan modal dari bank akan dikembalikan ketika masa perjanjian berakhir atau jatuh tempo.

Setiap pembiayaan memiliki risiko yang dihadapi oleh bank maupun nasabah. Adapun risiko dalam pembiayaan musyarakah, terutama dalam penerapannya dalam pembiayaan relatif tinggi, yaitu: ${ }^{2}$

1. Mitra tidak menggunakan dana pembiayaan sesuai dengan perjanjian.

1 Ascarya, Akad dan Produk Bank Syariah. (Jakarta: PT. Raja Grafindo Persada, 2007), 51.

2 M. Syafi'i Antonio, Bank Syariah Dari Teori ke Praktek, (Jakarta: Gema Insani Press, 2002), 94. 
2. Mitra melakukan kesalahan yang disengaja / lalai dalam tugasnya yang mengakibatkan suatu kerugian.

3. Ketidak jujuran mitra dalam memberikan informasi akan keuntungannya.

Berdasarkan faktor diatas dapat terlihat seberapa besar resiko pembiayaan bermasalah yang terjadi pada akad musyarakah, hal ini dapat mengakibatkan kerugian apabila tidak diatasi, pihak bank harus menutupinya terlebih dahulu dari dana cadangan kerugian yang ada pada setiap bank apabila terjadi pembiayaan bermasalah seperti ini. Berdasarkan pembiayaan bermasalah ini pula dapat terlihat juga kesehatan bank sangat berpengaruh dari bagaimana bank mengelola dana yang diterimanya. Suatu bank akan maju apabila dapat mengelola dana tersebut, dan usaha bank yang sering dilanda dengan pembiayaan bermasalah yang menumpuk akan likuidasi dengan cepat.

Hal inilah yang menjadi latar belakang penulis mengambil tema ini dengan judul "Penyelesaian Non-Performing Finance dalam Akad Musyarakah di Bank Kalsel Syariah" dengan tujuan agar dapat mengetahui bagaimana praktek yang dilakukan oleh bank apabila terjadi pembiayaan bermasalah yang sangat berpengaruh pada baik tidaknya suatu bank.

\section{Akad Musyarakah dalam Islam \\ A. Pengertian Musyarakah}

Musyarakah atau sering disebut syarikah atau syirkah berasal dari syaraka yang mempunyai arti sekutu atau teman peseroan, perkumpulan, perserikatan. ${ }^{3}$

Syirkah menurut bahasa mempunyai arti campur atau percampuran. Maksud dari percampuran disini adalah seseorang mencampurkan hartanya dengan harta orang lain sehingga antara bagian yang satu dengan bagian yang lainnya sulit untuk dibedakan lagi. ${ }^{4}$

Adapun secara terminologi ada beberapa pendapat ulama fiqh yang memberikan definisi syirkah, antara lain sebagai berikut:

Menurut Sayyid Sabiq syirkah adalah akad antara dua orang berserikat pada pokok harta (modal) dan keuntungan. ${ }^{5}$

\footnotetext{
${ }^{3}$ Ahmad Warson Munawwir, Al Munawnir, Kamus ArabIndonesia, (Yogyakarta, Al Munawwir, 1984), 765.

4 Ali bin Muhammad al Jurjani, al Ta'rifat, Jeddah: AlHaramain, 2001), 124.

5 Sayyid Sabiq, Fiqh al-Sunah, (Beirut-Libanon: Dar al Fikr), 294.
}

Menurut TM. Hasbi Ash Shiddieqi, syirkah adalah akad yang berlaku antara dua orang atau lebih untuk bekerjasama dalam suatu usaha dan membagi keuntungannya. ${ }^{6}$

Maka dapat diambil kesimpulan bahwa makna syariat syirkah adalah suatu akad antara dua pihak atau lebih, yang bersepakat untuk melakukan suatu usaha dengan tujuan memperoleh keuntungan.

\section{B. Dasar Hukum Musyarakah}

Hukum dari pelaksanaan syirkah adalah boleh selama sesuai dengan ketentuan yang mengaturnya. Kebolehan hukum syirkah ada dalam sumber pokok hukum Islam, yaitu alQur'an dan hadis, antara lain sebagai berikut:

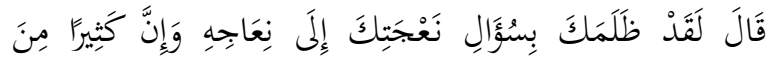

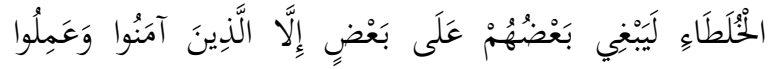

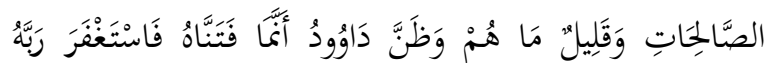

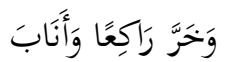

Artinya: "Daud berkata: Sesunggubnya Dia telah berbuat zalim kepadamu dengan meminta kambingmu itu untuk ditambahkan kepada kambingnya. Dan Sesunggubnya kebanyakan dari orang-orang yang berserikat itu sebahagian mereka berbuat zalim kepada sebabagian yang lain, kecuali orang-orang yang beriman dan mengerjakan amal yang saleb; dan amat sedikitlah mereka ini. dan Daud mengetabui babwa Kami mengujinya; Maka ia meminta ampun kepada Tubannya lalu menyungkur sujud dan bertaubat'. (al-Shaad ayat 24)

Hasbi as-Shiddieqi menjelaskan bahwa maksud dari ayat ini adalah bahwa kebanyakan orang yang bekerjasama atau berserikat itu selalu ingin merugikan mitra usahanya, kecuali mereka yang beriman dan melakukan amalan yang sholeh karena merekalah yang tidak mau mendhalimi orang lain. Tetapi alangkah sedikitnya jumlah orang-orang seperti itu. ${ }^{7}$

Kemudian hadis yang berisi firman Allah bahwa Ia merupakan pihak ketiga dalam perserikatan antara dua pihak juga merupakan dasar dari akad musyarakah ini.

Maka berdasarkan dalil dari al Qur'an dan Hadits tersebut para fuqaha telah sepakat bahwa secara umum hukum syirkah adalah

6 Hasbi Ash Shiddieqi, Pengantar Fiqh Muamalah, (Semarang, Pustaka Rizki Putra, 1999), 99.

${ }^{7}$ Hasbi Ash Shidieqi, Tafsir al Qur'anul Majid al Nuur, (Semarang: Pustaka Rizki Putra, 2000), 3505. 
mubah, meskipun mereka berselisih pendapat tentang hukum beberapa jenis syirkah tertentu.

\section{Rukun dan Syarat Musyarakah}

Terdapat perbedaan perndapat antara para ulama mengenai rukun syirkah. Ulama Hanafiyah menyebutkan bahwa rukun syirkah hanya dua, yaitu ijab dan qabul. Sebab ijab qabul (akad) yang menentukan adanya syirkah. ${ }^{8}$ Sedangkan mayoritas ulama merumuskan rukun dan syarat syirkah yang lebih kompleks, yaitu:

1. Sighat (ijab dan qabul)

Syarat sah dan tidaknya akad musyarakah tergantung pada sesuatu yang di transaksikan dan juga kalimat akad hendaklah mengandung arti izin untuk membelanjakan obyek syirkah dari mitranya. ${ }^{9}$

2. Al 'aqidain (dua orang yang melakukan akad)

Syarat orang yang melakukan akad musyarakah yaitu berakal, baligh, dan merdeka atau tidak dalam paksaan

Disyaratkan pula bahwa seorang mitra diharuskan berkompeten dalam memberikan kekuasaan perwakilan, dikarenakan dalam musyarakah mitra kerja juga berarti mewakilkan harta untuk diusahakan. ${ }^{10}$

3. Ma'qud alaib (obyek akad)

Objek akad dalam musyarakah terdiri dari dua hal, yaitu modal dan kerja. Modal dan kerja inilah yang dibagi kepada kedua belah pihak sesuai kesepakatan.

Adapun syarat syirkah secara umum terdiri dari tiga hal, yaitu: ${ }^{11}$

1. Perserikatan tersebut merupakan transaksi yang dapat diwakilkan.

2. Prosentase pembagian keuntungan untuk masingmasing pihak yang berserikat dijelaskan pada saat berlangsungnya akad.

3. Keuntungan itu diambilkan dari hasil laba harta perserikatan dan bukan dari harta lain.

Selain tiga syarat di atas tersebut, ada beberapa syarat khusus dalam pelaksanaan syirkah al-uqud, yaitu: ${ }^{12}$

\footnotetext{
8 Abdurrahman al Jaziri, al-Fiqh 'ala al-Madzahib alArba'ah, 71.

9 Sulaiman Rasyid, Fiqih Islam, (Bandung: Sinar Baru, 1992), 278.

10 Tim Pengembangan Perbankan Syariah, Konsep Produk dan Implementasi Operasional Bank Syariah, (Jakarta: Djambatan, 2001), 182.

${ }^{11}$ Hasbi Ash Shiddieqi, Pengantar Fiqh Muamalah, 102.
}

1. Dalam syirkah al amwal modal perserikatan haruslah jelas dan tunai, bukan berbentuk utang dan bukan pula berbentuk barang.

2. Modal sebagai obyek akad musyarakah adalah alat pembayaran (nuqud).

3. Modal (harta pokok) harus ada ketika pelaksanaan akad.

\section{Pembiayaan Bermasalah}

\section{A. Pengertian Pembiayaan Bermasalah}

Menurut Veithzal Rivai ada beberapa pengertian pembiayaan bermasalah, yaitu: ${ }^{13}$

1. Pembiayaan yang di dalam pelaksanaannya belum mencapai atau memenuhi target yang diinginkan oleh pihak bank.

2. Pembiayaan yang memiliki kemungkinan timbulnya risiko dikemudian hari bagi bank dalam arti luas.

3. Mengalami kesulitan di dalam penyelesaian kewajiban-kewajibannya, baik dalam bentuk pembayaran kembali pokoknya dan atau pembayaran bunga, denda keterlambatan serta biaya-biaya bank yang menjadi beban nasabah yang bersangkutan.

4. Pembiayaan dimana pembayaran kembalinya dalam bahaya, terutama apabila sumber-sumber pembayaran kembali yang diharapkan, diperkirakan tidak cukup untuk membayar kembali pembiayaan, sehingga belum memenuhi target yang diinginkan oleh bank.

5. Pembiayaan dimana terjadi cidera janji dalam pembayaran kembali sesuai perjanjian, sehingga terdapat tunggakan atau ada potensi kerugian di perusahaan nasabah sehingga memiliki kemungkinan timbulnya risiko dikemudian hari bagi bank dalam arti luas.

6. Pembiayaan golongan perhatian khusus, kurang lancar, diragukan dan macet serta golongan lancar yang berpotensi menunggak.

Menurut Ismail, pembiayaan bermasalah merupakan kredit yang telah disalurkan oleh bank, dan nasabah tidak dapat melakukan pembayaran atau melakukan angsuran sesuai

12 Hendi Suhendi, Fiqh Muamalat, Jakarta: Raja Grafindo Persada, 2002), 128.

${ }^{13}$ Veithzal Rivai, dan Andria Permanda Veithzal, Credit Management Handbook: Teori, Konsep, Prosedur dan Aplikasi Panduan Praktis Mahasiswa, Bankir dan Nasabah, (Jakarta: PT. RajaGrafindo Persada, 2006), 475. 
dengan perjanjian yang telah ditandatangani oleh bank dan nasabah. ${ }^{14}$

Maka berdasarkan dua definisi dan pengertian di atas dapat disimpulkan bahwa pembiayaan bermasalah merupakan pembiayaan yang mengindikasikan ketidakmampuan atau kesulitan yang dialami nasabah dalam pembayaran kembali angsuran atau kewajibannya kepada bank sesuai dengan perjanjian yang telah disepakati kedua belah pihak.

\section{B. Faktor Penyebab Pembiayaan Bermasalah}

Menurut Veithzal Rivai dalam bukunya Islamic Financial Management, adanya anggapan yang salah bahwa pembiayaan bermasalah selalu disebabkan oleh kesalahan debitur. Pembiayaan bermasalah dapat disebabkan oleh berbagai hal yang berasal dari debitur, dari kondisi eksternal, bahkan dari bank yang memberikan pembiayaannya tersebut. Kesalahan bank yang dapat mengakibatkan pembiayaan bermasalah berawal dari tahap perencanaan, tahap analisis, dan tahap pengawasan. Faktorfaktor yang menjadi penyebab timbulnya pembiayaan bermasalah tersebut perlu disadari oleh bank agar bank dapat mencegah atau menangani dengan baik.

Adapun beberapa hal yang menjadi penyebab timbulnya pembiayaan bermasalah adalah sebagai berikut: 15

1. Karena Kesalahan Bank atau Lembaga Keuangan Syariah

a. Kurang pengecekan terhadap latar belakang calon nasabah.

b. Kurang tajam dalam menganalisis terhadap maksud dan tujuan penggunaan pembiayaan dan sumber pembayaran kembali.

c. Kurang pemahaman terhadap kebutuhan keuangan yang sebenarnya dari calon nasabah dan apa manfaat pembiayaan yang diberikan.

d. Kurang mahir dalam menganalisis laporan keuangan calon nasabah.

e. Kurang lengkap dalam mencantumkan syarat-syarat.

f. Terlalu agresif atau terburu-buru.

g. Pemberian kelonggaran terlalu banyak.

${ }^{14}$ Ismail, Manajemen Perbankan dari Teori Menuju Aplikasi, (Jakarta: Kencana, 2010), 123.

15 Veithzal Rivai, Islamic Financial Management, (Jakarta: PT. Rajawali Press, 2007), 478-479. h. Kurangnya pengalaman pejabat pembiayaan atau account officer dalam melaksanakan tugas.

i. Mudah untuk dipengaruhi, diintimidasi, atau dipaksa oleh calon nasabah.

j. Keyakinan yang berlebihan.

k. Kurang mengadakan review, minta laporan, dan menganalisis laporan keuangan serta informasi-informasi kredit lainnya.

1. Kurang mengadakan kunjungan ke lokasi nasabah.

$\mathrm{m}$. Kurang mengadakan kontak dengan nasabah.

n. Pengikatan agunan kurang sempurna.

o. Adanya kepentingan pribadi pejabat bank.

p. Tidak punya kebijakan dalam pembiayaan yang sehat.

q. Sikap terlalu memudahkan, dari pejabat bank atau account officer.

2. Karena Kesalahan Nasabah atau Mitra Pembiayaan

a. Nasabah tidak kompeten dalam menjalankan usahanya.

b. Nasabah tidak atau kurang pengalaman.

c. Nasabah kurang memberikan waktu untuk usahanya.

d. Nasabah tidak jujur.

e. Nasabah serakah.

3. Karena Faktor Eksternal

a. Kondisi perekonomian

b. Perubahan-perubahan kebijakan atau peraturan pemerintah.

c. Bencana alam.

Berdasarkan penjelasan di atas dapat disimpulkan bahwa faktor-faktor yang menyebabkan terjadinya pembiayaan bermasalah, antara lain: Pertama, faktor yang disebabkan oleh pihak bank itu sendiri, seperti pihak bank kurang tajam dalam menganalisis terhadap maksud dan tujuan penggunaan pembiayaan oleh nasabah dan sumber pembayaran kewajibannya kembali. Kedua, faktor yang disebabkan oleh nasabah seperti nasabah tidak jujur kepada pihak bank dalam penggunaan dananya. Ketiga, faktor eksternal seperti perubahan peraturan atau kebijakan tentang ekonomi nasional oleh pemerintah dan terjadinya bencana alam yang menimpa nasabah.

\section{Upaya Penanganan Pembiayaan} Bermasalah

Penanganan pembiayaan bermasalah adalah bagian yang tidak dapat dihindari dalam proses pembiayaan, di dalam suatu institusi 
perbankan, maka penanganan pembiayaan yang bermasalah merupakan suatu hal yang sangat penting untuk dilakukan. Oleh sebab itu, jika diketahui adanya gejala suatu pembiayaan yang berpotensi bermasalah, bank harus segera mengambil langkah penanganan sebelum masalah tersebut menimbulkan kerugian bagi pihak bank. ${ }^{16}$

Proses penanganan pembiayaan bermasalah dilakukan sesuai dengan kolektabilitas pembiayaan, yaitu sebagai berikut: ${ }^{17}$

1. Pembiayaan lancar, dilakukan dengan cara:

a. Pemantauan usaha nasabah

b. Pembinaan anggota dengan pelatihanpelatihan

2. Pembiayaan potensial bermasalah, dilakukan dengan cara:

a. Pembinaan anggota

b. Pemberian dengan surat teguran

c. Kunjungan lapangan oleh sebagian pembiayaan kepada nasabah

d. Upaya preventif dengan penanganan rescheduling, yaitu penjadwalan kembali jangka waktu angsuran serta memperkecil jumlah angsuran juga dapat dilakukan dengan reconditioning, yaitu memperkecil keuntungan atau bagi hasil.

3. Pembiayaan kurang lancar, dilakukan dengan cara:

a. Membuat surat teguran atau peringatan

b. Kunjungan lapangan oleh sebagian pembiayaan kepada nasabah secara lebih bersungguh-sungguh.

c. Upaya penyehatan dengan cara rescheduling, yaitu penjadwalan kembali jangka waktu angsuran serta memperkecil margin keuntungan atau bagi hasil.

4. Pembiayaan diragukan dan macet, dilakukan dengan cara:

a. Dilakukan rescheduling, yaitu penjadwalan kembali jangka waktu angsuran serta memperkecil jumlah angsuran

b. Dilakukan reconditioning, yaitu memperkecil margin atau bagi hasil usaha

c. Dilakukan pengalihan atau pembiayaan ulang dalam bentuk pembiayaan Qardhul hasan.
Secara umum proses penyelesaian pembiayaan bermasalah dalam lembaga keuangan syariah atau bank dapat dilakukan dengan cara: ${ }^{18}$

1. Rescheduling, yaitu penjadwalan kembali jangka waktu angsuran pembiayaan serta memperkecil jumlah angsuran pembiayaan.

2. Reconditioning, yaitu perubahan sebagian atau seluruh syarat-syarat pembiayaan meliputi perubahan jadwal pembayaran angsuran, jangka waktu, dan margin.

3. Restructuring, yaitu tindakan bank kepada nasabah dengan cara menambah modal nasabah dengan pertimbangan nasabah memang membutuhkan tambahan dana atau usaha yang dibiayai masih layak.

4. Kombinasi, merupakan kombinasi dari ketiga jenis metode yang digunakan diatas. Misalnya kombinasi antara restructuring dengan reconditioning atau rescheduling dengan restructuring.

5. Penyitaan jaminan atau agunan yang merupakan jalan terakhir apabila nasabah sudah benar-benar tidak punya itikad baik atau sudah tidak mampu lagi dalam membayar utang-utangnya.

\section{Metode Penelitian}

Penelitian ini adalah penelitian berjenis lapangan dengan pendekatan kualitatif, yaitu dengan mengamati praktek penanganan pembiayaan bermasalah dalam akad musyarakah di Bank Kalsel Syariah, yang kemudian dianalisis secara kualitatif dengan menggunakan metode berfikir induktif, yaitu metode berfikir yang berpijak pada fakta yang bersifat khusus, kemudian diteliti sehingga ditemukan problem solving yang bersifat umum.

Adapun data yang dikumpulkan terdiri dari dua jenis, yaitu data primer yang digunakan sebagai dasar penelitian, dan data sekunder untuk bahan analisis. Data primer dikumpulkan dengan metode triangulasi antara data dokumen dan wawancara mengenai penanganan pembiayaan bermasalah dalam akad musyarakah di Bank Kalsel Syariah. Adapun data sekunder penulis kumpulkan dari berbagai literatur, terutama dari peraturan perundangan seperti Kompilasi Hukum Ekonomi

18 Kasmir, Dasar-dasar Perbankan, (Jakarta: PT. Raja
Syariah dan Fatwa MUI.

Garafindo Persada, 2003), 104 dan 131.
16 Muhammad, Manajemen Pembiayaan Bank Syariah, (Yogyakarta: UPP AMP YKPN, 2005), 168.

${ }^{17}$ Ibid, 268. 


\section{Pembahasan}

Bank Kalsel Syariah Cabang Banjarmasin menyediakan fasilitas pembiayaan musyarakah bagi nasabah. Untuk memperoleh pembiayaan musyarakah tersebut, terdapat prosedur yang mengatur agar pembiayaan dapat terlaksana dengan lancar.

Apabila terjadi pembiayaan bermasalah dalam akd musyarakah tersebut, Bank Kalsel Syariah menanganinya dengan melakukan beberapa tahapan sebagaimana yang disebutkan dalam Buku Pedoman Penanganan Pembiayaan Bermasalah, yakni dengan melakukan Pembayaran Secara Tunai, Restrukturisasi Pembiayaan, Penjualan Agunan, dan terakhir dengan Jalur Hukum atau Litigasi.

\section{A. Pembayaran Secara Tunai}

Penyelesaian dengan cara pembayaran tunai merupakan penyelesaian terbaik bagi Bank, sebab pembayaran tersebut akan memberikan kesempatan bagi Bank untuk menggunakan dana yang telah dikembalikan tersebut kepada alternatif investasi lainnya yang lebih menguntungkan dengan risiko yang lebih kecil, baik dalam bentuk pembiayaan maupun keperluan promosi.

Jumlah tunai yang akan diterima oleh Bank sedapat mungkin sama dengan jumlah kewajiban nasabah, yaitu pengembalian pokok dan pembayaran bagi hasil sesuai dengan periode yang disepakati, walaupun tidak tertutup kemungkinan Bank akan memberikan keringanan dalam penyelesaian tersebut melalui level direksi.

\section{B. Penyelamatan Pembiayaan Melalui Restrukturisasi Akad}

Restrukturisasi pembiayaan adalah upaya perbaikan yang dilakukan Bank dalam kegiatan penyediaan dana terhadap Nasabah yang mengalami kesulitan untuk memenuhi kewajibannya dengan mengikuti ketentuan regulator dan sesuai dengan prinsip syariah. Restrukturisasi pembiayaan merupakan suatu usaha penyelesaian pembiayaan yang berdasarkan pada kepercayaan semua pihak terutama pihak Bank sebagai pemberi fasilitas, dengan tujuan setelah restrukturisasi, kinerja dan prospek usaha nasabah akan menjadi lebih baik, sehingga dapat membayar angsuran pembiayaan dengan lancar.

Restrukturisasi harus dilakukan dengan menerapkan prinsip dasar pemahaman di atas, pihak nasabah harus menunjukkan itikad baik, jujur dan terbuka serta secara sungguh-sungguh menyusun rencana usaha dan skema restrukturisasi sesuai kemampuan yang dimiliki.
Dalam penyelesaian ini dilakukan proses revitalisasi yaitu dengan secara bertahap dari penjadwalan kembali (rescheduling), penambahan syarat baru (reconditioning), maupun penggunaan struktur baru (restructuring). Adapun penjelasan lengkap mengenai urutan revitalisasi ini yaitu sebagai berikut:

1. Penjadualan kembali (rescheduling)

Restrukturisasi yang dilakukan dengan memperpanjang jangka waktu jatuh tempo Pembiayaan tanpa mengubah sisa kewajiban nasabah yang harus dibayarkan kepada Bank.

2. Persyaratan kembali (reconditioning);

Restrukturisasi yang dilakukan dengan menetapkan kembali syarat- syarat pembiayaan tanpa menambah sisa kewajiban nasabah yang harus dibayarkan kepada Bank. Syarat-syarat yang dapat ditinjau ulang tersebut antara lain yaitu:
a. nisbah bagi hasil,
b. jumlah angsuran,
c. jangka waktu,
d. jadwal pembayaran,
e. pemberian potongan pokok dan/atau lainnya

3. Penataan kembali (restructuring) dengan penambahan dana.

Restrukturisasi yang dilakukan dengan penambahan dana oleh Bank kepada nasabah agar kegiatan usaha nasabah dapat kembali berjalan dengan baik.

4. Penataan kembali (restructuring) dengan melakukan konversi menjadi Surat Berharga Syariah Berjangka Waktu Menengah, yaitu dengan tahapan sebagai berikut:

a. Bank menghentikan akad Pembiayaan dalam bentuk mudharabah atau musyarakah,

b. Bank membuat akad Mudharabah atau Musyarakah dengan nasabah untuk Surat Berharga Berjangka Waktu Menengah yang diterbitkan oleh nasabah atas dasar proyek yang dibiayai,

c. Bank memiliki Surat Berharga Syariah Berjangka Waktu Menengah paling tinggi sebesar sisa kewajiban nasabah

5. Penataan kembali (restructuring) dengan melakukan konversi menjadi Penyertaan Modal Sementara, dengan tahapan sebagai berikut :

a. Penyertaan Modal Sementara hanya dapat dilakukan pada nasabah yang merupakan badan usaha berbentuk hukum Perseroan Terbatas, 
b. Bank menghentikan akad pembiayaan dalam bentuk Mudharabah atau Musyarakah,

c. Bank membuat akad Musyarakah dengan nasabah untuk Penyertaan Modal Sementara sesuai kesepakatan dengan nasabah atas usaha yang dilakukan,

d. Bank melakukan Penyertaan Modal Sementara sebesar sisa kewajiban nasabah. Sisa kewajiban nasabah dalam restrukturisasi akad Pembiayaan dalam bentuk Mudharabah atau Musyarakah sebagaimana dimaksud diatas merupakan jumlah pokok yang belum dibayar oleh nasabah pada saat dilakukan restrukturisasi.

\section{Penyelamatan Pembiayaan Melalui Jaminan}

Penyelesaian melalui jaminan dilakukan Bila berdasarkan hasil evaluasi ulang pembiayaan, nasabah sudah tidak memiliki usaha dan nasabah tidak kooperatif untuk menyelesaikan pembiayaan, dan proses revitalisasi tidak berhasil dilakukan. Artinya, alternatif terakhir apabila dua cara sebelumnya tidak membuahkan hasil, yaitu dengan cara melelang agunan.

Hasil penjualan agunan diprioritaskan untuk pengembalian pokok, namun jika tidak mencukupi sisa pokoknya dapat dihapus melalui persetujuan direksi.

Secara teknis, sebelum melakukan proses penjualan agunan tersebut harus diperhatikan terlebih dahulu jenis agunan atau asset yang akan diserahkan, lokasi, nilai pasar, nilai likuidasi, kondisi fisik dan dokumennya (tidak dalam sengketa), kesiapan untuk dijual kembali serta kemungkinan biaya yang akan timbul.

D. Penyelesaian Melalui Jalur Litigasi

Litigasi adalah penyelesaian pembiayaan melalui jalur hukum yang dilakukan melalui Pengadilan, dalam hal ini ialah Pengadilan Agama. Penyelesaian melalui jalur hukum ini hanya dilakukan apabila nasabah benar-benar tidak kooperatif dalam menyelesaikan pembiayaan. Sedapat mungkin dihindari karena memerlukan waktu dan biaya yang besar.

Penanganan Pembiayaan Musyarakah yang Bermasalah pada Bank Kalsel Syariah dalam Perspektif Hukum Ekonomi Syariah

Berdasarkan keterangan-keterangan di atas, diketahui bahwa dalam menangani pembiayaan bermsalah pada akad musyarakah, Bank Kalsel Syariah melakukannya dengan beberapa tahapan, yakni dengan pembayaran secara tunai, revitalisasi pembiayaan melalui restrukturisasi akad, penyelesaian melalui jaminan, dan terakhir melalui jalur hukum.

Walaupun DSN belum mengatur secara spesifik mengenai pedoman penanganan pembiayaan bermasalah pada akad musyarakah, namun dalam Keputusan DSN-MUI NO.01/DSN-MUI/X/2013 tentang Pedoman Implementasi Musyarakah Mutanaqishah Dalam Produk Pembiayaan terdapat ketentuan mengenai penyelesaian pembiayaan bermasalah. Dengan demikian, tata cara penanganan pembiayaan bermasalah dalam akad musyarakah dapat diqiyaskan kepada aturan tersebut, yaitu yang berbunyi:

1. Pembiayaan bermasalah dapat diselesaikan oleh para pihak melalui musyawarah mufakat dengan cara penjadwalan kembali (rescheduling), penambahan syarat baru (reconditioning), maupun penggunaan struktur baru (restructuring).

2. Bank Syariah/LKS dapat melakukan penyelesaian (settlement) Pembiayaan Musyarakah Mutanaqishah bagi nasabah yang tidak menyelesaikan atau melunasi pernbiayaannya sesuai jumlah dan waktu yang telab disepakati, dengan ketentuan:

a. Aset Musyarakab Mutanaqishab atau jaminan lainnya dijual oleb nasabah rnelalui Bank. Syariab/LKS dengan harga yang disepakati;

b. Nasabah melunasi sisa kewajibannya kepada Bank Syariab/LKS dari hasil penjualan;

c. Apabila hasil penjualan melebibi sisa utang, maka Bank Syariab/LKS mengembalikan sisanya kepada nasabab;

d. Apabila hasil penjualan lebih kecil dari sisa utang maka sisa utang tetap menjadi utang nasabah;

e. Apabila nasabah tidak mampu membayar sisa utangnya, maka Bank Syariah/LKS dapat membebaskannya berdasarkan kebijakan Bank Syariah/LKS.

Selain itu, terdapat pula ketentuan mengenai penyelesaian perselisihan pada Fatwa DSN No. 114/DSN-MUI/IX/2017 tentang Akad Syirkah. Adapun bunyi lengkapnya yaitu sebagai berikut:

1. Jikea salab satu pibak tidak menunaikan kewajibannya atau jika terjadi perselisiban di antara para pihak, maka penyelesaiannya dilakukan melalui lembaga penyelesaian sengketa berdasarkan syariah sesuai dengan peraturan perundang-undangan yang berlaku setelah tidak tercapai kesepakatan melalui musyawarah.

2. Penerapan fatwa ini dalam kegiatan atau produk usaha wajib terlebih dabulu mendapatkan opini dari Dewan Pengawas Syariah. 
3. Fatwa ini berlaku sejak tanggal ditetapkan dengan ketentuan jika di kemudian hari ternyata terdapat kekeliruan, akan diubah dan disempumakan sebagaimana mestinya.

Dewan Syariah Nasional adalah lembaga resmi dan diakui oleh negara untuk menerbitkan fatwa ataupun aturan mengenai hukum ekonomi syariah yang wajib dijalankan oleh seluruh perbankan syariah.

Dengan demikian, kedua aturan tersebut dapat menjadi tolak ukur atas legalitas praktek penanganan pembiayaan bermasalah pada akad musyarakah di Bank Kalsel.

Maka, jika dibandingkan antara praktek penanganan pembiayaan musyarakah yang bermasalah pada Bank Kalsel Syariah dengan aturan di atas, maka terlihat bahwa terdapat kesesuaian dan ketidaksesuaian antara keduanya, yang dapat disimpulkan dalam tabel berikut:

\begin{tabular}{|c|c|}
\hline Kesesuaian & Ketidaksesuaian \\
\hline $\begin{array}{l}\text { Penyelesaian melalui restrukturisasi } \\
\text { dan penjualan agunan sesuai dengan } \\
\text { DSN-MUI No.1 Tahun } 2013\end{array}$ & $\begin{array}{l}\text { Opsi penyelesaian melalui pembayaran secara tunai } \\
\text { tidak diatur dalam kedua ketentuan tersebut }\end{array}$ \\
\hline $\begin{array}{l}\text { Penyelesaian melalui jalur litigasi sesuai dengan } \\
\text { Fatwa DSN No.114 Tahun } 2017\end{array}$ & \\
\hline
\end{tabular}

Tabel tersebut menunjukkan bahwa sebagian praktek penanganan pembiayaan musyarakah yang dilakukan oleh Bank Kalsel syariah sudah sesuai dengan aturan DSN, namun ada satu praktek yang tidak diatur DSN, yaitu mengenai penyelesaian secara tunai. Kenyataan ini kemudian melahirkan pertanyaan baru, yaitu apakah pembiayaan bermasalah pada akad musyarakah dapat diselesaikan melalui pembayaran tunai? Dan apakah cara penyelesaian tersebut dapat dibenarkan di mata hukum ekonomi syariah?

Secara teoritis musyarakah merupakan Natural Uncertainty Contract yang keuntungannya tidak dapat dipastikan setiap bulan/tahunnya, karena sangat tergantung kepada kinerja nasabah dan kondisi ekonomi.

Oleh karena itu, tidak mungkin kewajiban nasabah berupa pembayaran bagi hasil diberikan secara tunai untuk bank, kecuali pada proyek tertentu seperti kontraktor/perumahan yang keuntungannya jelas dan terukur, atau nasabah hanya diminta mengembalikan pokok secara tunai tanpa dibebani biaya bagi hasil.

Maka, opsi ini hanya dapat diterapkan secara kondisional dalam situasi-situasi tertentu saja.

Kemudian untuk pertanyaan kedua mengenai pandangan hukum ekonomi syariah terhadap penyelesaian pembiayaan bermasalah melalui pembayaran tunai, dalam hal ini penulis berpendapat bahwa cara tersebut boleh dilakukan namun kurang tepat apabila diterapkan dalam akad musyarakah. Sebab hal ini kembali lagi kepada karakteristik akad musyarakah yang keuntungan bagi hasilnya tidak pasti. Berbeda dengan akad murabahah atau istishna yang memiliki kepastian margin sehingga bisa ditunaikan pembayaran pokok dan marginnya. Kecuali bank hanya meminta pengembalian pokok saja tanpa membebankan bagi hasil maka cara ini dapat dilakukan.

Dengan demikian, dapat disimpulkan bahwa secara umum praktek penyelesaian pembiayaan bermsalah pada akad musyarakah di Bank Kalsel Syariah telah sesuai dengan syariat dan Fatwa DSN.

\section{Kesimpulan}

Berdasarkan keterangan-keterangan di atas, dapat ditarik kesimpulan bahwa dalam menangani pembiayaan bermsalah pada akad musyarakah. Bank Kalsel Syariah melakukannya dengan beberapa tahapan, yakni dengan pembayaran secara tunai, revitalisasi pembiayaan melalui restrukturisasi akad, penyelesaian melalui jaminan, dan terakhir melalui jalur hukum.

Selanjutnya, walaupun DSN belum mengatur secara spesifik mengenai pedoman penanganan pembiayaan bermasalah pada akad musyarakah, namun dalam Keputusan DSN-MUI NO.01/DSN-MUI/X/2013 tentang Pedoman Implementasi Musyarakah Mutanaqishah Dalam Produk Pembiayaan terdapat ketentuan mengenai penyelesaian pembiayaan bermasalah. Secara umum praktek penyelesaian pembiayaan bermsalah pada akad musyarakah di Bank Kalsel Syariah telah sesuai dengan ketentuan pada keputusan DSN tersebut.

Maka, disarankan kepada nasabah pembiayaan musyarakah dan perbankan syariah untuk dapat memenuhi perjanjian yang telah disepakati dan menghindari wanprestasi, agar tidak menyebabkan kerugian kepada satu atau kedua 
belah pihak. Terkhusus kepada pihak DSN selaku legislator bagi lembaga keuangan syariah, disarankan untuk segera merumuskan aturan khusus mengenai penanganan pembiayaan bermasalah pada akad musyarakah yang dapat diterapkan agar tidak menimbulkan kerancuan hukum bagi perbankan syariah dan nasabahnasabahnya.

\section{Daftar Pustaka}

A.Riawan Amin, Menata Perbankan Syariah di Indonesia, Jakarta: UIN Press, 2009.

Abdullah Saeed, Islamic Banking and Interest A Study of The Probibition of Riba and its Comtemporery Interpretation, Terj. Muhammad Ufuqul Mubin, Yogyakarta: Pustaka Pelajar, 2004.

Abdurrahman al Jaziri, al-Fiqh 'ala al-Madzahib alArba'ah, Juz 3, Lebanon Dar Al-Kutub AlIlmiyyah, 1990.

Ahmad Warson Munawwir, Al Munawwir, Kamus Arab-Indonesia, Yogyakarta, Al Munawwir, 1984.

Ali bin Muhammad al Jurjani, al Ta'rifat, Jeddah: Al-Haramain, 2001.

Ascarya, Akad Dan Produk Bank Syariah, Jakarta : Rajagrafindo Persada, 2011.

Chairuman Pasaribu dan Suhrawardi K. Lubis, Hukum Perjanjian dalam Islam, Jakarta: Sinar Grafika, 1996.

Ghufron A. Masadi, Figh Muamalab Kontekstual, Jakarta: RajaGrafindo Persada, 2002.

Hasbi Ash Shiddieqi, Pengantar Fiqh Muamalah, Semarang, Pustaka Rizki Putra, 1999.

Hasbi Ash Shidieqi, Tafsir al Qur'anul Majid al Nuur, Semarang: Pustaka Rizki Putra, 2000.

Hendi Suhendi, Fiqh Muamalat, Jakarta: Raja Grafindo Persada, 2002.

Irwan Soehartono, Metode Penelitian Sosial, Bandung: Remaja Rosdakarya, 1995.

Ismail, Manajemen Perbankan dari Teori Menuju Aplikasi, Jakarta: Kencana, 2010.
Kasmir, Dasar-dasar Perbankan, Jakarta: PT. Raja Garafindo Persada, 2003.

Lexy J, Moloeng, Metode Penelitian Kualitatif, Bandung: Rosdakarya, 2004.

M. Syafi'i Antonio, Bank Syariah Dari Teori ke Praktek, Jakarta: Gema Insani Press, 2002.

M. Syafi'i Antonio, Bank Syariah: Suatu Pengenalan Umum, Jakarta: Tazkia Institute, 1999.

Muhammad, Manajemen Dana Bank Syariah, Yogyakarta: UPP AMP YKPB, 2005

Muhammad, Manajemen Pembiayaan Bank Syariah, Yogyakarta: UPP AMP YKPN, 2005.

Saifuddin Azwar, Metode Penelitian Yogyakarta: Pustaka Pelajar, 2004.

Sayyid Sabiq, Fiqh al-Sunah, Beirut-Libanon: Dar al Fikr.

Sugiyono, Memahami Penelitian Kualitatif, Bandung: CV. Alfabeta, 2009.

Sulaiman Rasyid, Fiqih Islam, Bandung: Sinar Baru, 1992.

Sumadi Suryabrata, Metodologi Penelitian, Jakarta: PT. Raja Grapindo Persada, 1998.

Sutrisno Hadi, Metodologi Research Yogyakarta: Andi Offset, 2000.

Tim Pengembangan Perbankan Syariah, Konsep Produk dan Implementasi Operasional Bank Syariah, Jakarta: Djambatan, 2001.

Veithzal Rivai, dan Andria Permanda Veithzal, Credit Management Handbook: Teori, Konsep, Prosedur dan Aplikasi Panduan Praktis Mahasiswa, Bankir dan Nasabah, Jakarta: PT. RajaGrafindo Persada, 2006.

Veithzal Rivai, Islamic Financial Management, Jakarta: PT. Rajawali Press, 2007

Wahbah al Zuhaili, Figh al-Islami wa Adillatubu, Bairut: Dar al Fikr.

Zainal Arifin, Dasar-Dasar Manajemen Bank Syariah, Jakarta: Pustaka Alvabet, 2006. 